\title{
Cytogenetic abnormalities in the buccal cells of twenty-thirty-year-old miners from the Murmansk region Petrashova D. ${ }^{1}$, Pozharskaya V. ${ }^{2}$, Murav'ev S. ${ }^{3}$ Цитогенетические нарушения в буккальном эпителии у горнорабочих Мурманской области в возрасте до тридцати лет Петрашова Д. А. ${ }^{1}$, Пожарская В. В. ${ }^{2}$, Муравьев С. В. ${ }^{3}$
}

\author{
${ }^{1}$ Петрашова Дина Александровна / Petrashova Dina - кандидат биологических наук, научный сотрудник; \\ ${ }^{2}$ Пожарская Виктория Викторовна / Pozharskaya Viktoria - кандидат биологических наук, \\ младший научный сотрудник; \\ ${ }^{3}$ Муравьев Сергей Владимирович / Murav'ev Sergey-инженер, \\ Кольский научный ияентр \\ Российская Академия Наук, г. Апатиты
}

\begin{abstract}
Аннотация: приведены данные по цитогенетическим нарушениям у молодых горнорабочих в возрасте 20-30 лет, занятых на добыче руды, содержащей редкоземельные элементы, в Мурманской области. Показано, что у молодых работников горнорудного производства в первые годы трудовой деятельности на фоне снижения интенсивности апоптоза и увеличения скорости обновления буккального эпителия возрастает общая частота ичттогенетических нарушений в клетках буккального эпителия, в частности растет частота встречаемости клеток с микроядрами, а также увеличивается частота встречаемости клеток с признаками нарушения пролиферации.

Abstract: the data on cytogenetic disturbances in young miners aged 20-30 years engaged in the extraction of ore containing rare-earth elements in Murmansk region. It is shown that with the young workers of mining production in the first years of work in the background to reduce the intensity of apoptosis and increase the refresh rate of buccal epithelium increases the overall frequency of cytogenetic abnormalities in buccal cells, particularly increasing the frequency of cells with micronucleus and increases the frequency of cells with signs of proliferation.
\end{abstract}

Ключевые слова: микроядра, микроядерный тест, буккальный эпителий, горнорабочие. Keywords: micronucleus, micronucleus test, buccal cells, miners.

Подземная разработка руды, содержащей такие природные радионуклиды, как уран, торий, радий, представляет определенную опасность для здоровья горных рабочих вследствие смешанного облучения различными видами ионизирующего излучения: вдыхание/глотание пылевых частиц, содержащих радий, вдыхание радона и продуктов его распада, внешнее облучение тела, вдыхание пыли смешанных частиц радиоизотопов.

В статье приведены данные по горнорабочим в возрасте 20-30 лет, поскольку для них характерны меньший уровень патологий, накопленных со временем, и более низкая вероятность смены места работы по состоянию здоровья или за счет карьерного роста [1].

Материалы и методы исследования

Материалом исследования служили образцы буккального эпителия работников горнообогатительного комплекса (ГОК), работающих на производстве, связанном с добычей и обогащением лопаритовых руд, которые, наряду с ценными металлами, содержат примеси природных радионуклидов, заряженные частицы которых оседают на пыли и взвесях, содержащихся в шахтном пространстве, и являются источником смешанных видов ионизирующего излучения. Помимо этого в шахтах содержится радон в повышенных концентрациях. Первым барьером, возникающим на пути у канцерогенов, поступающих в организм при дыхании, с водой и с пищей, являются клетки буккального эпителия [2]. Группа молодых работников горнорудного производства (20-30 лет) состояла из 49 мужчин со стажем работы от 1 года до 9 лет. Контрольная группа состояла из 7 мужчин (19-28 лет), чья трудовая деятельность не связана с вредными факторами.

Взятие биологического материала проводилось в 2013 году в рамках ежегодного медицинского осмотра работников горнорудного производства [3]. Обследуемые интервьюировались по специально разработанному опроснику на наличие вредных привычек и медикаментозного лечения. Процедура приготовления препаратов буккального эпителия проводилась в соответствии с методикой, описанной в работе [4]. Все полученные данные вносились в реляционную многопользовательскую базу данных [5]. Анализ препаратов осуществлялся с помощью микроскопа Микмед-6 (ЛОМО, Россия) (увеличение 10x40; 10x100), оснащенного цифровыми камерами.

Анализ частоты встречаемости клеток с генетическими нарушениями и цитотоксическими эффектами проводился на отдельно лежащих и распластанных клетках с подсчетом не менее 1000 клеток на каждом препарате. Микроядра идентифицировали согласно стандарту, описанному в работе [6]. Кроме того, 
учитывались двуядерные клетки, ядра с насечкой, кариопикноз, кариорексис, кариолизис, фрагментация и вакуолизация ядра, нарушения типа ядерных почек.

Статистическая обработка материала проводилась согласно рекомендациям Международной рабочей группы по оценке генотоксичности [7].

Результаты и обсуждение

Группа горнорабочих была разделена на подгруппы по стажу таким образом, чтобы в каждой подгруппе было не менее 7 человек. Объем выборки и производственный стаж для каждой подгруппы указаны в таблице.

Средние значения частот встречаемости клеток с микроядрами в контрольной группе не превышают среднепопуляционные показатели 2-5\% [6]. Имеется тенденция по увеличению частоты встречаемости клеток с микроядрами у работников с двухлетним стажем на горнорудном производстве (табл.). Микроядра являются обособленной частью генетического материала за пределами основного ядра, которая либо представлена фрагментом хромосомы, образовавшимся в результате повреждения ДНК, либо одной или несколькими целыми хромосомами, отставшими в анафазе и не вошедшими в основное ядро [8]. Повышение частоты клеток с микроядрами в ротовой полости является самым ранним проявлением риска рака ротовой полости [9].

Таблица 1. Средние значения и предель варьирования кариологических показателей клеток буккального эпителия обследуемых групп

\begin{tabular}{|c|c|c|c|c|c|c|}
\hline Показатели, \% & \multicolumn{6}{|c|}{ Стаж работы на горнорудном производстве, лет } \\
\hline & $\mathbf{0}$ & 1 & 2 & $3-4$ & 5 & 6-9 \\
\hline Выборка, человек & 7 & 7 & 12 & 8 & 10 & 12 \\
\hline \multicolumn{7}{|c|}{ Цитогенетические показатели } \\
\hline $\begin{array}{c}\text { Частота клеток с } \\
\text { цитогенетическими } \\
\text { повреждениями, всего: }\end{array}$ & $\begin{array}{c}6.8 \pm 2.27 \\
(0-15)\end{array}$ & $\begin{array}{l}9.1 \pm 3.17 \\
(0-20)\end{array}$ & $\begin{array}{l}15.2 \pm 3.47 \\
(3-42)\end{array}$ & $\begin{array}{l}9.6 \pm 3.54 \\
(0-30)\end{array}$ & $\begin{array}{c}9.4 \pm 2.91 \\
(0-30)\end{array}$ & $\begin{array}{l}13.7 \pm 2.81 \\
(4-39)\end{array}$ \\
\hline $\begin{array}{c}\text { Частота клеток с } \\
\text { микроядрами }\end{array}$ & $\begin{array}{l}5.0 \pm 1.70 \\
(0-12)\end{array}$ & $\begin{array}{c}6.5 \pm 2.56 \\
(0-20)\end{array}$ & $\begin{array}{l}8.9 \pm 1.76 \\
(2-20)\end{array}$ & $\begin{array}{c}9.3 \pm 3.64 \\
(0-30)\end{array}$ & $\begin{array}{c}7.5 \pm 2.99 \\
(0-30)\end{array}$ & $\begin{array}{c}8.2 \pm 1.75 \\
(0-19)\end{array}$ \\
\hline $\begin{array}{c}\text { Частота клеток с ядерными } \\
\text { почками }\end{array}$ & $\begin{array}{l}1.7 \pm 1.20 \\
(0-8)\end{array}$ & $\begin{array}{l}0.6 \pm 0.57 \\
\quad(0-4)\end{array}$ & $\begin{array}{c}1.7 \pm 1.01 \\
(0-11)\end{array}$ & $\begin{array}{l}0.3 \pm 0.30 \\
\quad(0-3)\end{array}$ & $\begin{array}{l}0.4 \pm 0.37 \\
\quad(0-4)\end{array}$ & $\begin{array}{l}0.6 \pm 0.40 \\
(0-4)\end{array}$ \\
\hline $\begin{array}{c}\text { Частота клеток с ядром } \\
\text { атипичной формы }\end{array}$ & - & $\begin{array}{l}0.7 \pm 0.71 \\
\quad(0-5)\end{array}$ & $\begin{array}{c}4.4 \pm 2.42 \\
(0-28)\end{array}$ & - & - & $\begin{array}{l}2.8 \pm 2.24 \\
(0-24)\end{array}$ \\
\hline \multicolumn{7}{|c|}{ Показатели пролиферации } \\
\hline $\begin{array}{c}\text { Частота клеток с } \\
\text { нарушениями } \\
\text { пролиферации, всего: }\end{array}$ & $\begin{array}{l}1.2 \pm 0.77 \\
(0-6)\end{array}$ & $\begin{array}{c}8.4 \pm 2.94 \\
(0-20)\end{array}$ & $\begin{array}{l}5.7 \pm 3.05 \\
(0-37)\end{array}$ & $\begin{array}{l}1.9 \pm 1.35 \\
(0-11)\end{array}$ & $\begin{array}{l}4.8 \pm 1.80 \\
(0-14)\end{array}$ & $\begin{array}{l}2.8 \pm 1.66 \\
(0-18)\end{array}$ \\
\hline $\begin{array}{c}\text { Частота клеток с двумя } \\
\text { ядрами }\end{array}$ & $\begin{array}{l}1.2 \pm 0.77 \\
\quad(0-6)\end{array}$ & $\begin{array}{c}7.3 \pm 2.36 \\
(0-15)\end{array}$ & $\begin{array}{l}3.2 \pm 1.09 \\
(0-9)\end{array}$ & $\begin{array}{l}1.9 \pm 1.35 \\
(0-11)\end{array}$ & $\begin{array}{l}4.2 \pm 1.63 \\
(0-14)\end{array}$ & $\begin{array}{l}1.4 \pm 0.89 \\
(0-10)\end{array}$ \\
\hline $\begin{array}{c}\text { Частота клеток с круговой } \\
\text { насечкой }\end{array}$ & - & $\begin{array}{c}1.1 \pm 1.14 \\
(0-8)\end{array}$ & $\begin{array}{c}2.2 \pm 1.92 \\
(0-23)\end{array}$ & - & $\begin{array}{c}0.6 \pm 0.59 \\
(0-6)\end{array}$ & $\begin{array}{c}1.4 \pm 1.27 \\
(0-15)\end{array}$ \\
\hline
\end{tabular}

Частота встречаемости клеток с ядерными почками существенно не отличалась между исследуемыми группами. В целом, по общему количеству цитогенетических нарушений клеточного ядра сохраняется тенденция к возрастанию их частоты у работников с производственным стажем два года.

Клетки с ядрами атипичной формы обнаруживались при стаже работы 1-2 года и 6 и более лет. Согласно литературным данным, данная патология может быть обусловлена неправильным расположением хроматина в ядре [10], а также смещением положения интерфазных хромосом в результате хромосомных аберраций в митозе или нарушения веретена деления при анеуплоидии [4].

Схожая картина наблюдается и для показателей нарушения пролиферации: частоты встречаемости двуядерных клеток и клеток с круговой насечкой. Помимо этого, у одного горнорабочего с двухлетним стажем в возрасте 28 лет была обнаружена трехядерная клетка буккального эпителия. Есть данные, что 
двуядерные и многоядерные клетки образуются преимущественно в результате полиплоидизируещего ацитокинетического митоза [11] и их частота может повышаться в ответ на облучение [12].

Для оценки интенсивности обновления буккального эпителия в исследуемых группах проведен анализ кардиологических показателей ранней и поздней стадий деструкции ядра. Установлено, что частота дифференцированных клеток возрастает при достижении двулетнего производственного стажа, а затем незначительно снижается. Клетки на ранней стадии деструкции ядра в основном представлены клетками с конденсацией хроматина в ядре: их частота в контрольной группе достоверно ниже в два раза, что свидетельствует о большей скорости обновления клеток буккального эпителия у горнорабочих (рис. 1).

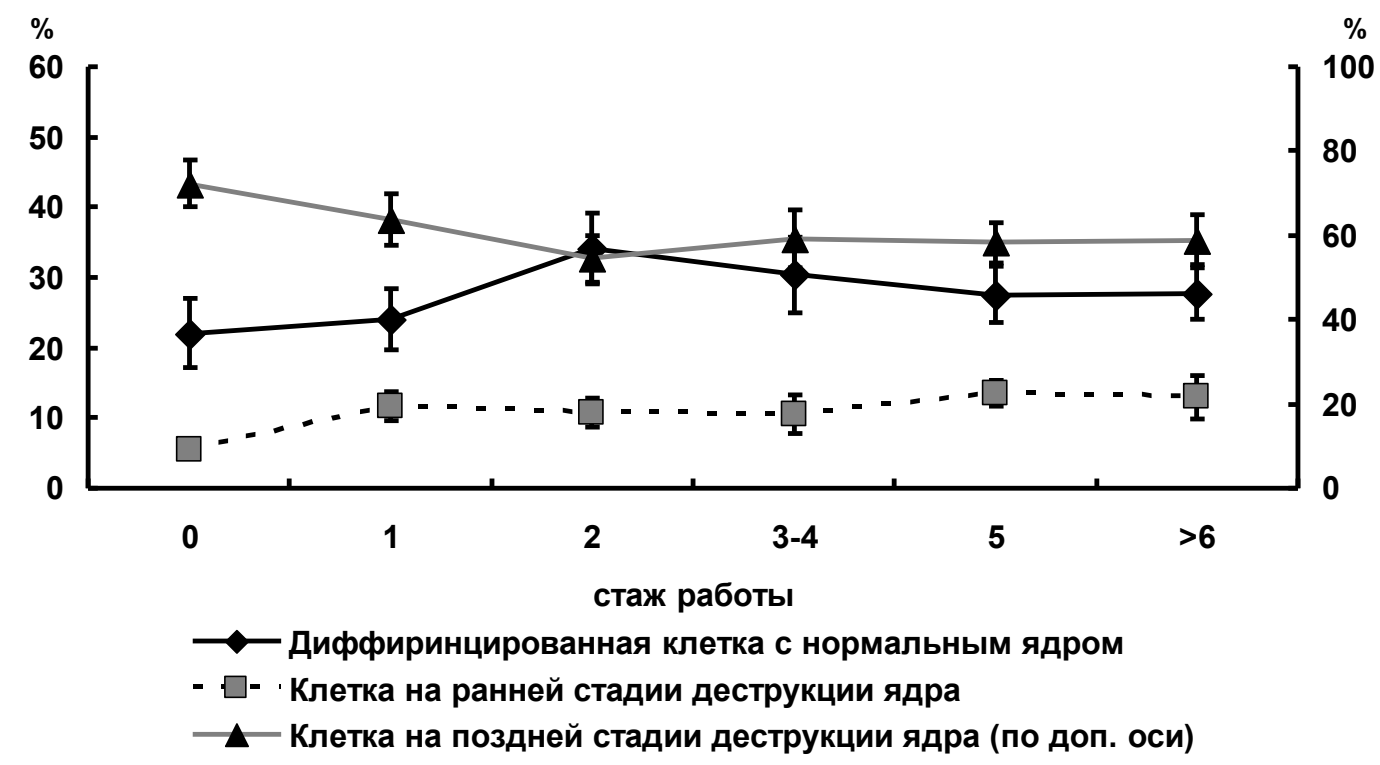

Рис. 1. Частота встречаемости клеток буккального эпителия с нормальным ядром и клеток на разных стадиях деструкиии ядра в зависимости от производственного стажа

Немного противоположная картина наблюдается для частоты клеток на поздней стадии деструкции ядра: при достижении двухлетнего стажа происходит ее снижение, и в дальнейшем она не меняется (рис. 2). Основной вклад в частоту встречаемости клеток на поздней стадии деструкции ядра вносят кариолизис (10-85\% по образцам) и фрагментация ядра (0-24\% по образцам). На рисунке 2 видно, что частота встречаемости клеток с кариолизисом выше в контрольной группе.

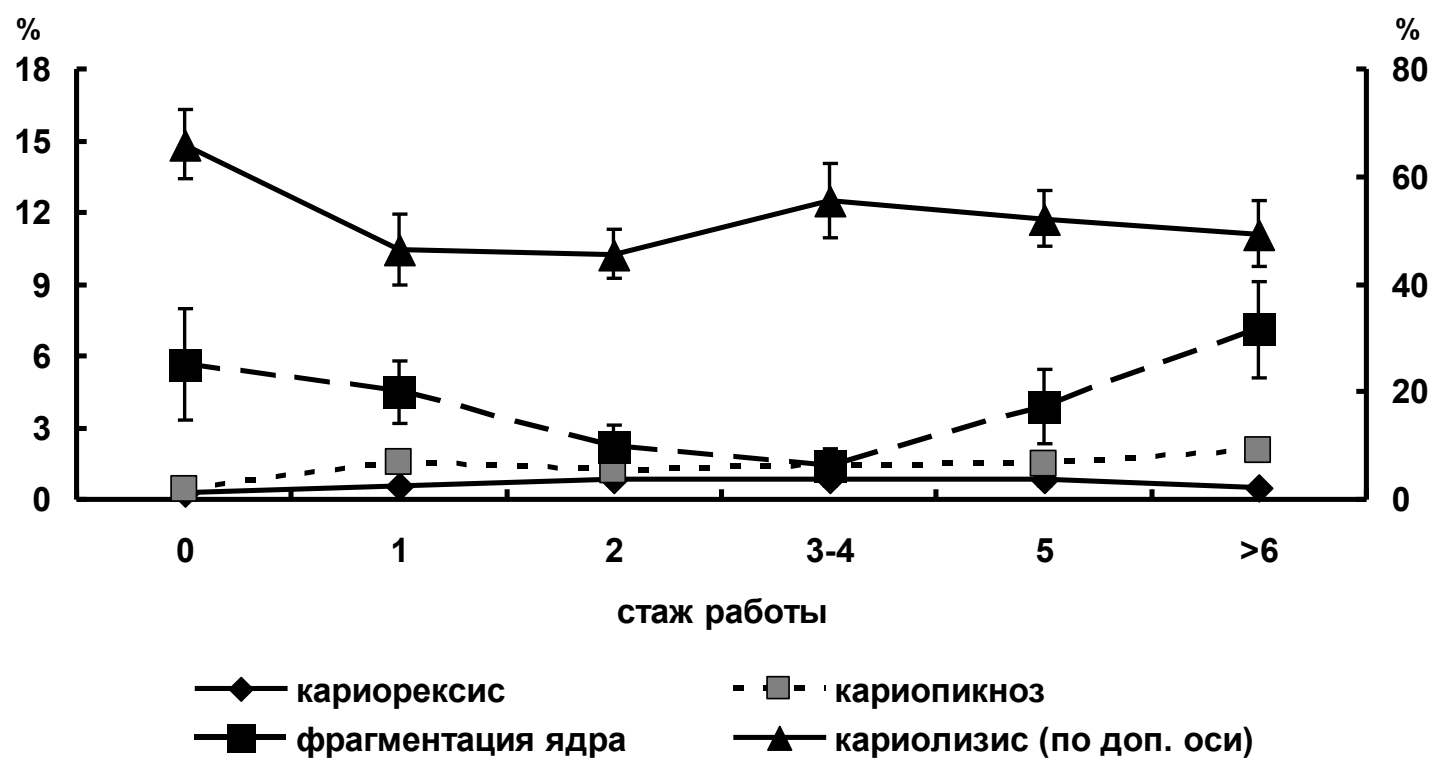

Рис. 2. Частота встречаемости клеток буккального эпителия на поздних стадиях деструкции ядра в зависимости от производственного стажа 
Частота встречаемости клеток с фрагментацией ядра (образование апоптозных тел) снижается при двухлетнем производственном стаже и начинает расти при стаже 5 и более лет. Известно, что интенсификация апоптоза является механизмом удаления из популяции дефектных клеток с цитогенетическими нарушениями [13].

\section{Заключение}

У молодых работников горнорудного производства в первые годы трудовой деятельности возрастает общая частота цитогенетических нарушений в клетках буккального эпителия, в частности растет частота встречаемости клеток с микроядрами, а также увеличивается частота встречаемости клеток с признаками нарушения пролиферации. Эти изменения происходят на фоне снижения интенсивности апоптоза и увеличения скорости обновления буккального эпителия, которое проявляется в возрастании частоты встречаемости клеток буккального эпителия с конденсацией хроматина ядра.

Таким образом, у горнорабочих первые несколько лет трудовой деятельности клетки буккального эпителия с нарушениями элиминируются с меньшей скоростью и мы, вероятно, наблюдаем накопительный эффект. Полученные результаты согласуются с литературными данными о том, что у людей цикл адаптивной перестройки в новой экологической и климатической зоне с субэкстремальными условиями длится 2-3 года [14]. Следовательно, начало работы в условиях горнорудного производства можно отнести к новому стрессовому воздействию на организм, в том числе и на клеточном уровне.

\section{Лuтература}

1. Петрашова Д. А., Пожарская В.В. О проблеме анализа многофакторного воздействия в цитогенетических исследованиях на примере микроядерного теста в клетках буккального эпителия человека // Труды XII Всеросс. науч. шк. «Математические исследования в естественных науках». Апатиты. 26-27 октября 2015 г. Апатиты: Изд-во К \& M, 2015. С. 189-197

2. Holland N., Bolognesi C., Kirsch-Volders M. et al. The micronucleus assay in human buccal cells as a tool for biomonitoring DNA damage. The HUMN project perspective on current status and knowledge gaps // Mutat. Res., 2008. Vol. 659 (1-2). P. 93-108.

3. Петрашова Д. А., Пожарская В. В., Завадская Т. С., Белишева Н. К. Цитогенетические эффекты воздействия природных источников ионизирующего излучения на работников горно-рудного производства Мурманской области // Вестник Уральской медицинской академической науки, 2014. T. 48. № 2. C. 40-42.

4. Мейер А. В., Дружинин В.Г., Ларионов А. В. и др. Генотоксические и цитотоксические эффекты в буккальных эпителиоцитах детей, проживающих в экологически различающихся районах Кузбасса // Цитология, 2010. Т. 52. № 4. С. 305-310.

5. Петрашова Д. А., Буриев А. В. Разработка базы данных по микроядерному тесту на клетках человека // Вестник Кольского научного центра РАН, 2016. № 2. С. 124-136.

6. Tolbert P. E., Shy C. M., Allen J.W. Micronuclei and other nuclear anomalies in buccal smears: methods development // Mut. Res.,1992. 271. P. 69-77.

7. Kirsch-Volders M., Sofuni T., Aardema M. et al. Report from the in vitro Micronucleus assay working group // Environmental and molecular mutagenesis, 2000. 35. P. 167-172.

8. Сычева Л. П. Биологическое значение, критерии определения и пределы варьирования полного спектра кариологических показателей при оценке цитогенетического статуса человека // Мед. Генетика, 2007. № 6 (11). C. 3-11.

9. Cardozo R. S, Takahashi-Hyodo S., Peitl P. Jr. et al. Evaluation of chromosomal aberrations, micronuclei and sisiter chromatid exchanges in hospital workers chronically exposed to ionizing radiation // Teratog. Carcinog. Mutagen, 2001. 21. Pp. 431-439.

10. Баллаж $A$. Биология опухолей. Сомнения и надежды. М.: Мир, 1987. 206 с.

11.Бродский В. Я., Урываева И. В. Клеточная полиплоидия, пролиферация и дифференцировка. М.: Наука, 1981. 237 c.

12. Koss L. G. Diagnostic cytology and its histopathologic bases. Philadelphia. Toronto: J. B. Lippincott Co. 1, 2 , 1979. $1266 \mathrm{p}$.

13. Джамбетова П. М., Молочаева Л. Г., Махтиева А.Б. и др. Оценка влияния загрязнения почв нефтепродуктами на цитогенетический статус и показатели апоптоза в клетках буккального эпителия у детей // Экол. Генетика, 2009. № 4. С. 34-40.

14. Физиология человека. Под ред. В. М. Покровского, Г. Ф. Коротько. М., 2003. 656 с. 